\title{
PETROGRAPHY OF ALKALINE VOLCANIC-SUBVOLCANIC ROCKS FROM THE BRAZILIAN FERNANDO DE NORONHA ARCHIPELAGO, SOUTHERN ATLANTIC OCEAN
}

\author{
M.N.C. Ulbrich
}

KEY-WORDS: oceanic islands, petrography of alkaline rocks, Fernando de Noronha, dikes and flows.

ULBRICH, M.N.C. (1993) Petrography of alkaline volcanic-subvolcanic rocks from the Brazilian Fernando de Noronha Archipelago, Southern Atlantic Ocean, Bol. IG-USP, Sër. Cient., 24:77-94.

\section{ABSTRACT}

A classification scheme for the volcanic-subvolcanic rocks of the Fernando de Noronha Archipelago is presented, following the IUGS recommendations, based on the petrographic study of a large number of samples. In Fernando de Noronha two main volcanic events were defined by Almeida (1955): an older Remédios Formation (12 to $8 \mathrm{Ma}$ old) composed of domes, plugs and dikes of tephritic-basanitic to trachytic and phonolitic compositions, with essexite porphyries, limburgites and alkaline lamprophyres intruding basal pyroclastic rocks, and a younger Quixaba Formation ( 3 to 2 Ma), made up mostly by flows of nephelinitic composition (ankaratrites). The lamprophyres were separated in two groups: tephritic or melanocratic lamprophyres and typical lamprophyres, the first ones belonging to a suite characterized by continuous increase in amphibole content. Most of the rocks of the Remédios Formation appear to belong to two distinct petrographic series, one represented by an undersaturated sodic basanite-tephrite (essexite)-phonolite trend and the other by a potassic alkali basalt-trachyandesite-trachyte series, while the limburgites and lamprophyres are of uncertain ancestry.

Some ankaratrite and olivine nephelinite dikes that only cut the Remédios rocks are also attributed to the Quixaba Formation. The basanitic flow with mantle xenoliths of the São José Island, considered by Almeida (1955) to form the youngest São Jose Formation, is here tentatively interpreted as representing the waning stages of the Quixaba volcanism.

\section{RESUMO}

Apresenta-se neste trabalho um esquema de classificaça para as rochas vulcânicas do Archipelago de Fernando de Noronha, com base no estudo de um grande nùmero de amostras.

Dois eventos vulcânicos principais foram definidos em Fernando de Noronha por Almeida (1955). A Formação Remédios é a mais antiga (12 a $8 \mathrm{Ma}$ ), composta por domos, "plugs" e diques e por depositos piroclásticos basais por eles cortados, que apresentam composiçôes variando de tefritos-basanitos a traquitos 
e fonolitos, junto com essexitos pórfiros, limburgitos e lamprófiros alcalinos. A formaçăo mais nova, a de Quixaba, é constituida principalmente por derrames de nefelinitos (ankaratritos). Os lamprófiros foram separados em dois grupos: lamprófiros tefriticos ou melanocráticos e lamprófiros típicos, os primeiros pertencendo a uma suite caracterizada pelo aumento contínuo no conteudo modal de anfibólio. As rochas da Formaçāo Remédios parecem pertencer a duas séries petrográficas, uma subsaturada, de tendência sódica, representada por basanitos-tefritos (essexitos)-fonolitos e a outra de tendência potássica constituida por alkali basaltos-traquiandesitostraquitos. Os lamprófiros e limburgitos șăo de origem duvidosa.

Alguns diques que cortam a Formação Remédios (ankaratritos $\mathrm{c}$ nefelinito) foram atribuidos à Formação Quixaba. Os derrames de basanitos com xenólitos mantélicos da Illa de São José, que Almeida (1955) atribui a uma formaçăo mais nova, a de São Josć, são aquí considerados como pertencentes aos cstágios finais do vulcanismo nefelinitico da Formaçăo Quixaba.

\section{INTRODUCTION}

In recent years there has been an increasing interest in the geochemistry of ocean island rocks with the intention of obtaining more information about their mantle sources as well as the compositional variations of the oceanic mantle as a whole (Sun \& McDonough, 1989; Weaver, 1991, and references therein).

Recent review papers and detailed geochemical and isotopic work on the rocks of several Atlantic oceanic islands are based on the foundations of many previous petrographic and geologic studies (i.e., Chaffey et al., 1989; Davies et al., 1989; Schmincke, 1982).

The only comprehensive work dealing with the geology and petrography of the Fernando de Noronha Archipelago is the classic paper by Almeida (1955) which presents, along with the geologic map and some outstanding petrographic descriptions, the now commonly used stratigraphic division. A summary of the work of Almeida and a historical review with comments on petrography and geochemical trends is given by Mitchell-Thomé (1970).

Almeida (1955) used many varietal names to characterize rock types, following a common practice in earlier years, particularly in relation to alkaline rocks. Subsequent work (Gunn \& Watkins, 1976; Cornen, 1986; Weaver, 1990) introduced new rock names, or used rather loosely a simplified IUGS classification of volcanic rocks without proper description and location of samples, thus confusing the occasional reader.

It is the aim of this contribution to present the results of petrographic studies on a collection of rock samples from Fernando de Noronha, discussing the stratigraphic setting and petrography of the rather bewildering variety of rock types found in Fernando de Noronha, at the same time addressing the issue of a proper petrographic nomenclature. Geochemical aspects were discussed in Ulbrich et al. (1994a).

\section{GEOLOGICAL SETTING, STRATI- GRAPHY AND K-Ar AGES}

The Archipelago of Fernando de Noronha, $345 \mathrm{~km}$ off the northeastern Brazilian coast, at latitude $3^{\circ} 51^{\prime} \mathrm{S}$ and longitude $32^{\circ} 25^{r} \mathrm{~W}$, consists of a main island and about 20 islets with a total area of $18.4 \mathrm{~km}^{2}$ (Fig. 1).

It is composed of volcanic and subvolcanic rocks constituting the exposed upper part of a large volcanic structure that emerges, as the westernmost expression of a submerged volcanic chain, from a depth of about $4000 \mathrm{~m}$ (Bryan et al., 1972). 


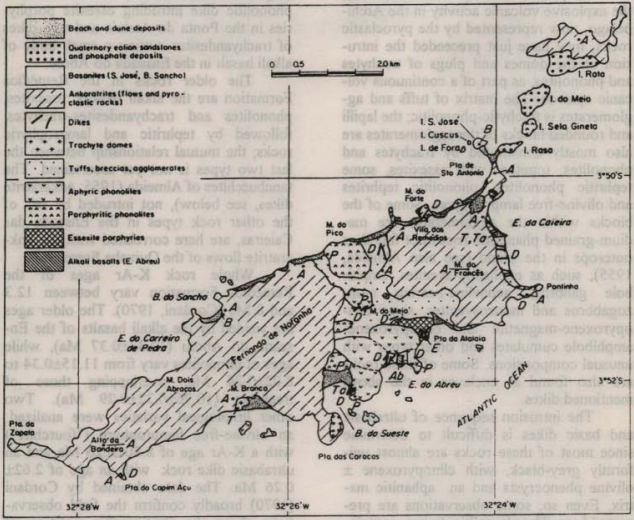

Figure 1 - Geological map of the Fernando de Noronha Archipelago (simplified after Almeida, 1955), showing

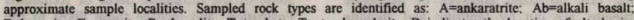
$\mathrm{B}$ =basanite; $\mathrm{E}$ =essexite; $\mathrm{P}$-phonolite; $\mathrm{T}$-trachyte; $\mathrm{Ta}=$ trachyandesite, $\mathrm{D}$ indicates the location of ultrabasicbasic dikes. For detailed information see Table 1 .

Abreviations: $\mathrm{B}=$ baia, $\mathrm{E}$-enseada, $\mathrm{I}=$-ilha, $\mathrm{M}=$ morro, $\mathrm{P}$ ta=ponta.

The geological features and the stratigraphic relationships were characterized by Almeida (1955), who recognized two main eruptive events of alkaline volcanism, the older Remédios Formation and the younger Quixaba Formation, separated by an erosional hiatus (Fig. 1).

The Remédios Formation, present mostly in the central part of the main island and in the coastal areas, is composed of abundant pyroclastic rocks (agglomerates, breccias, tuffs) intruded by subvolcanic domes of phonolites, plugs of trachytes, a sill-like body of essexite porphyry and numerous dikes of ultrabasic (ankaratrites, limburgites, basanites and tephrites) to basic-intermediate compositions (tephrites, phonolitic tephrites, tephritic phonolites, phonolites, alkali basalts, trachyandesites, trachytes and alkaline lamprophyres). 
As pointed out by Almeida (1955), the explosive volcanic activity in the Archipelago, now represented by the pyroclastic rocks, may have just preceeded the intrusion of the domes and plugs of trachytes and phonolites, as part of a continuous volcanic episode. The matrix of tuffs and agglomerates is trachytic-phonolitic; the lapili and rounded blocks of the agglomerates are also mostly constituted by trachytes and phonolites, together with essexites, some tephritic phonolites, phonolitic tephrites and olivine-free lamprophyres. Some of the blocks within the agglomerates are medium-grained phaneritic rocks not found as outcrops in the island (see also Almeida, 1955), such as nepheline syenites, amphibole gabbros, nepheline-bearing monzogabbros and monzosyenites, some clinopyroxene-magnetite and clinopyroxeneamphibole cumulates and other types with unusual compositions. Some of these rocks are also found as enclaves in the above mentioned dikes.

The intrusion sequence of ultrabasic and basic dikes is difficult to determine since most of these rocks are almost uniformly grey-black, with clinopyroxene \pm olivine phenocrysts and an aphanitic matrix. Even so, some observations are presented here. The phonolitic domes, containing rare dm-sized enclaves of nepheline syenite, are cut by tephritic and alkaline lamprophyric dikes, which commonly present irregularly shaped enclaves of nepheline syenites and isolated crystals of feldspar and nepheline; lamprophyric breccias with abundant rounded clasts of feldspar have also been found. In the Enseada das Caieiras of the main island (Fig. 1; Table 1), where a dike complex is more clearly exposed, trachytes and trachyandesites are cut by ultrabasic-basic and lamprophyric dikes (see also Almeida, 1955 , p. 28). A small trachyandesite pipe intrudes phonolites in the Baia do Sueste
(Fig.1). Almeida (1955) also mentions a phonolitic dike intruding essexite porphyries in the Ponta do Atalaia and two dikes of trachyandesites cutting a small body of alkali basalt in the Enseada do Abreu.

The older rocks in the Remédios Formation are the alkali basalts, essexites, phonolites and trachyandesites-trachytes, followed by tephritic and lamprophyric rocks; the mutual relationship between the last two types is not yet ascertained. The tannbuschites of Almeida (1955; ankaratrite dikes, see below), not intruded by any of the other rock types in the Enseada das Caieiras, are here correlated with the ankaratrite flows of the Quixaba Formation.

Whole rock $\mathrm{K}$-Ar ages of the Remédios Formation vary between 12.3 and $8 \mathrm{Ma}$ (Cordani, 1970). The older ages are yielded by the alkali basalts of the Enseada do Abreu (12.32 $\pm 0.37 \mathrm{Ma})$, while ages of phonolites vary from $11.15 \pm 0.34$ to $8.02 \pm 0.24 \mathrm{Ma}$, overlapping those of trachytes $(10.76 \pm 0.32 \pm 0.29 \mathrm{Ma})$. Two other lithological varieties were analized: an olivine-free lamprophyre ("fourchite") with a $\mathrm{K}-\mathrm{Ar}$ age of $8.80 \pm 0.26 \mathrm{Ma}$ and an ultrabasic dike rock with an age of $2.62 \pm$ $0.26 \mathrm{Ma}$. The data obtained by Cordani (1970) broadly confirm the field observations about the stratigraphic position of some of the ultrabasic dikes of Remédios Formation, and include these dikes in the later volcanic event which produced the lavas of the Quixaba Formation (see below).

The Quixaba Formation, deposited following a period of quiescence, is mainly constituted by extensive flows of ultrabasic lavas, now exposed in the western and eastern parts of the main island and in some islets (Fig. 1). In some places, the lavas are more than $200 \mathrm{~m}$ thick. A careful study of the thickness, extension and dip of the lava flows in the western part of the island allowed Almeida (1955) to pinpoint the existence of volcanic vents, now submerged, 
Table 1 - Location of sampled ultrabasic-basic dikes.
Location
Dike rock type
Wall rock

Coastal areas

\begin{tabular}{|c|c|c|}
\hline Enseada da Caieira & Ankaratrites, & Pyroclastic rocks \\
\hline 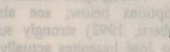 & $\begin{array}{l}\text { limburgites, } \\
\text { tephritic lamprophyres, } \\
\text { tephritic lamprophyres }\end{array}$ & \\
\hline Pontinha & Nephelinite & Ankaratrite flow \\
\hline Enseada do Abreu & $\begin{array}{l}\text { Ankaratrites, } \\
\text { tephrites, basanites, } \\
\text { tephritic lamprophyres }\end{array}$ & $\begin{array}{l}\text { Pyroclastic rocks, } \\
\text { phonolite dome }\end{array}$ \\
\hline Ponta do Atalaia & $\begin{array}{l}\text { Tephrites, } \\
\text { tephritic lamprophyres } \\
\text { typical lamprophyres }\end{array}$ & $\begin{array}{l}\text { Essexite porphyry sil } \\
\text { pyroclastic rocks }\end{array}$ \\
\hline Baia do Sueste & Limburgites & Phonolite dome \\
\hline Morro do Forte & $\begin{array}{l}\text { Tephritic lamprophyres } \\
\text { typical lamprophyres }\end{array}$ & Phonolite dome \\
\hline Vila dos Remédios & Ankaratrite & Ankaratrite flow \\
\hline Ponta do Capim Açú & Ankaratrite & Ankaratrite flow \\
\hline सा & when ont & \\
\hline Interior of the main island & 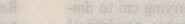 & \\
\hline Morro do Meio & $\begin{array}{l}\text { Tephrites, } \\
\text { typical lamprophyres }\end{array}$ & $\begin{array}{l}\text { Phonolite dome. } \\
\text { pyroclastic rocks }\end{array}$ \\
\hline Essexite porphyry sill & $\begin{array}{l}\text { Tephrites, } \\
\text { tephritic lamprophyres }\end{array}$ & $\begin{array}{l}\text { Essexite porphyry si } \\
\text { pyroclastic rocks }\end{array}$ \\
\hline Close to the Morro do Pico & $\begin{array}{l}\text { Typical lamprophyres, } \\
\text { olivine nephelinite }\end{array}$ & Pyroclastic rocks \\
\hline
\end{tabular}

along the northern coast in the Enseada do Carreiro de Pedra; he also stressed that ankaratritic pipes, such as those exposed in the Peninsula de Santo Antonio (close to the Ponta de Santo Antonio, see Fig. 1), acted as additional vents responsible for the extrusion of ultramafic lavas. The Morro do Francês, on the other hand, is clearly a volcano, as shown by shape and outline and the presence on its slopes of lavas and abundant oxidized scoria, and is certainly the vent that expelled flows of ankaratrites present in the vicinity and, possibly, in the whole eastern part of the main island.

Ankaratrites are dominant among the 
ultrabasic lavas, with scarce levels of melilite ankaratrites intercalated with breccias and tuffs. The flows are commonly intruded by dikes of the same composition (ankaratrites, nephelinites). Recently, an intrusive basanitic pipe was recognized in the Baia do Sancho (Ulbrich \& Ruberti, 1992).

Five whole rock K-Ar ages (Cordani, 1970) of ankaratrite flow samples vary from $3.33 \pm 0.11$ to $1.81 \pm 0.13 \mathrm{Ma}$; a single sample (a block found on the beach, close to the Morro Branco) is $6.64 \pm 0.20 \mathrm{Ma}$ old. Of the five samples, three are from the eastern flows (Morro do Francês, 2 samples, $3.33 \pm 0.11-2.96 \pm 0.52 \mathrm{Ma}$; Ilha Rata, $1.81 \pm 0.13 \mathrm{Ma})$ and two from the western flows (Ponta do Capim Açu, $2.49 \pm 0.09 \mathrm{Ma}$ and Morro dos Dois Abraços, 2.99 \pm 0.27 $\mathrm{Ma}$ ).

The stratigraphic record and the age determinations clearly state the contemporaneity of the ultrabasic volcanism in both the eastern and western parts of the Archipelago.

Besides the Remédios and the Quixaba formations, Almeida (1955) also described basanitic flows carrying $\mathrm{cm}$ to $\mathrm{dm}$ sized mantle xenoliths (dunites, peridotites) which form the islets São José, Cuscus and de Fora (Fig. 1). The volcanic basanites are only found in these islets and there are no visible contacts between them and the rocks of either the Remédios or the Quixaba Formations. However, the NNE dip of the ankaratrite lavas along the coast of the main island in the vicinity of the basanitic outcrops suggests that these lavas underlie the basanites. Almeida (1955) thus suggested that the basanites are the younger rocks of the Archipelago and grouped them into a separate unit, the São José Formation.

Whole rock $\mathrm{K}-\mathrm{Ar}$ dating gave ages of around $9.5 \mathrm{Ma}$ on selected samples of the São José basanites, indicating instead a broad contemporaneity with the rocks of the Remédios Formation; these ages may be misleading since there is a possibility of contamination of the basanite samples by incompletely degassified mantle xenoliths and xenocrysts (Cordani, 1970).

Petrographic characteristics (cf. descriptions below; see also Ulbrich \& Ruberti, 1992) strongly suggest that the São José basanites actually belong to the Quixaba volcanic cycle.

\section{PETROGRAPHY}

The described rocks will be separated according to stratigraphic setting and association in the field, and grouped on account of their petrographic characteristics. Section A, B and C will deal with the rocks attributed to the Remédios and Quixaba Formations, and a short final description depicts some of the features of the basanites of the Ilha de São José (section D). Table 2 shows a summary of the stratigraphic attribution of the several rock types and is a guide for the following descriptions. The pyroclastic rocks of the Remédios Formation are generally very poorly exposed and mostly altered, covered by vegetation and converted to soils. They will not be described here, and the interested reader is referred to Almeida's account (1955).

a) Subvolcanic plugs and domes of the Remédios Formation and associated dikes.

1 - Phonolitic tephrites to tephritic phonolites and their coarser-grained varieties. The rocks are mostly holocrystalline and form a small body and several dikes. In general, pyroxene is the main mafic phase with subordinate olivine $(6-8 \%)$, about $5 \%$ of opaque grains and $50 \%$ or more of felsic components. Some rocks of this group show glassy groundmass and are seen as narrow dikes. 
Table 2 - Stratigraphy and rock types in Fernando de Noronha.

\section{Stratigraphic attribution (1)}

São José basanite flow

Baia do Sancho basanite pipe

Quixaba Formation Ankaratrite dikes

Nephelinite dikes

Ankaratrite flows

Tephrite, basanite dikes

Typical lamprophyres dikes

Amphibole-rich tephrite, tephritic lamprophyre dikes

Trachyte plugs, dikes

Remédios Formation Trachyandesite plugs, dikes

Phonolite domes

Essexite porphyry sill

Alkali basalt plug

Lapilli tuffs, breccias, agglomerates
Varietal and other names used in the literature

K-Ar ages (2)

(Ma)

Tannbuschites (1)

Ankaramites $*(3,5)$, limburgites * $(3) \quad 3.3$ to 1.8 Nepheline basalts* $(6)$

Nephelinites, basanites* (6)

Pyroxene fourchites (1)

Olivina teschenites (1)

Camptonites (1)

Fourchites, nosean sannaites, melanocratic monchiquites (1)

Allcali trachytes (1)

Kali-gauteites (1), tristanites (3), benmoreites (4)

11.1 to 8.0

9.2 to 9.7

Hawaiites (3)

a - Pyroclastic rocks and ankaratrite flows are the oldest registered events in the Remédios and Quixaba formations, respectively: the rest of the stratigraphic sequence is unclear and only tentative. See text for comments. b - Almeida (1955) considers these rocks as part of the younger Såo José Formation, but they may actually belong to the Quixaba volcanism as a culminating phase (which may also be also the case for the Baia do Sancho basanites).

References: 1) Almeida (1955); (2) Cordani (1970), (3) Gun \& Watkins (1976); (4) Corner (1986); (5) Schwab \& Bloch (1985); (6) Weaver (1990).

Improper names, see text.

The coarse-grained rocks are porphyritic with aphanitic matrix, but finergrained equigranular phaneritic rocks are also found. The felsic minerals are plagio- clase (labradorite to andesine), K-feldspar, and nepheline or analcime, in variable proportions. The most abundant variety of this group are the essexite porphyries nepheline 
monzogabbros to monzodiorites), which form a sill-like body (Fig. 1). Other types are less common and occur as dikes. Almeida (1955) mentions glenmuirites (analcime monzogabbros) and allochetites (nepheline monzosyenites). The only varietal name that is worth maintaining is essexite porphyry, not only because of its geological importance and historical record in the literature on the Archipelago but also because "essexite" is commonly used for similar rocks in other oceanic islands (e g. Cabo Verde; Furnes \& Stillman, 1987).

$$
\text { The essexite porphyries }
$$

(inequigranular, coarse-grained equivalents of phonolitic tephrites), are slightly to strongly porphyritic with subidiomorphic phenocrysts of yellow-pink to greenish pyroxene (titanaugite to salitic? pyroxene) and resorbed irregular olivine grains (5$7 \%$ ) bordered by flakes of biotite and opaque grains. Labradorite appears as phenocrysts and microphenocrysts mantled by alkali feldspar. Some larger idiomorphic opaques and feldspathoids (nosean, hauyne?) are also seen. The matrix is formed by unoriented plagioclase laths with alkali feldspar, idiomorphic nepheline and apatite, opaque grains and small flakes of reddish, highly pleochroic biotite.

A rock with analcime instead of nepheline appears as a block in the Enseada das Caieiras. The analcime also substitutes for alkali feldspar; graphic intergrowths between alkali feldspar and analcime are ubiquitous.

A glassy tephritic phonolite dike has fresh amphibole in the phenocryst assemblage together with clinopyroxene, apatite, a mineral of the sodalite family and scarce opaque grains immersed in fresh fluidal glass $(70 \%$ of the rock) with needles of apatite.

2 - Domes of phonolites. The phonolites constitute the domes that appear in the central part of the main island and some islets and also occur as dikes. The rocks vary from almost aphyric to highly porphyritic types; usually, one of the two textures predominates in some areas or in individual domes, as clearly shown by Almeida's mapping (Fig. 1).

Aphyric phonolites are greenish rocks with conchoidal fractures. They have $<1$ to $3 \%$ of small phenocrysts of alkali feldspar and idiomorphic nepheline, with minor isotropic feldspathoid (sodalite?) filled with tiny opaque inclusions, titanite and kaersutitic amphibole, the last one always bordered by aegirine-augite and opaque grains. The very fine-grained matrix consists of flow-oriented alkali feldspar laths and tiny aegirine prisms, either isolated or gathered in divergent sheafs, plus idiomorphic nepheline and isotropic feldspathoid (sodalite?).

Porphyritic phonolites are grayish, porphyritic rocks with variable amounts of phenocrysts (from \pm 20 up to $\pm 40 \%$ ). The felsic phenocryst assemblage is similar to that of the aphyric rocks except for some textural features. In the porphyritic rocks, some alkali feldspar laths bordered by small opaque inclusions show discontinuous overgrowths of clean feldspar; also, glomerules of nepheline and sodalite(?) are common. The mafic assemblage consists of kaersutitic amphibole, clinopyroxene, opaque grains and titanite. The zoned idiomorphic to rounded amphibole crystals are partially substituted by opaque material and totally surrounded by aegirine-augite prisms and opaque grains. The pyroxenes may ocurr as isolated or grouped prisms and almost always present an irregular yellowish slightly pleochroic (augitic?) core bordered by aegirine-augite with external idiomorphic shapes. The matrix shows a trachytic texture produced by oriented abundant alkali feldspar laths; other matrix minerals are nepheline, rods of aegirinic pyroxene and interstitial analcime. 
3 - Dikes and plugs of alkali basalts, trachybasalts, basaltic trachyandesites, trachyandesites and trachyles. Altered alkali basalts were described by Almeida (1955) in the Baia do Sueste; fresh material, studied in this work, was found in the same small body sampled by Almeida (1955), located in the Enseada do Abreu (Fig.1, Table 2). More common are varieties of trachyandesites and trachytes, which ocurr as dikes and also form small pipes and plugs intruding pyroclastic rocks and, rarely, also phonolites. A dome of trachytes constitutes the Morro Branco (Fig. 1).

Basic to intermediate rocks such as these are commonly found in oceanic islands, usually separated into sodic or potassic series, characterized in previous classifications by several chemical parameters, particularly the $\mathrm{K}_{2} \mathrm{O} / \mathrm{Na}_{2} \mathrm{O}$ ratio (equal to, or less than, 1:2 for the sodic types; Wilkinson, 1974). Differences in this ratio are the only criterion maintained in recent classification schemes for these rocks (Le Maitre, 1989).

The literature on Fernando de Noronha registers several varietal names used to define rocks of the sodic series, such as hawaiite (trachybasalt; Cornen, 1986), mugearite (basaltic trachyandesite; Gerlach et al., 1987) and benmoreite (trachyandesite; Weaver, 1990). The available chemical data of the more basic types in Fernando de Noronha do not show a strong $\mathrm{Na}$ enrichment, as is the case for the type rocks of Hawaii or the Hebrides (Wilkinson, 1974). In the case of the more abundant dikes of trachyandesites, the situation seems to be the opposite, most samples being actually mildly (to strongly) potassic (cf. Ulbrich et al., 1994a; also the "benmoreite" analized by Weaver, 1990, with $2.19 \% \mathrm{Na}_{2} \mathrm{O}$ and $7.27 \% \mathrm{~K}_{2} \mathrm{O}$ ). The potassic character of these trachyandesites was recognized by Almeida (1955) who named them gauteites (cf. Le Maitre,
1989), with the addition of the prefix "kali" (kaligauteites) to register the absence or rarity of sodic plagioclase. Cornen (1986) preferred the name tristanite (cf. Le Maitre, 1989) to point out some similarities with the mildly potassic trachyandesites of Tristan da Cunha and Gough Island. In the IUGS classification the K-rich trachyandesites would be named latites.

Confusion arises from the use of different classification criteria by the different authors who define a rock name as a result of the total alkali content irrespective of the $\mathrm{K}_{2} \mathrm{O} / \mathrm{Na}_{2} \mathrm{O}$ ratios. Cox et al (1979), for instance, designate all alkali-rich rocks of the trachybasalt-trachyandesite group as hawaiites, mugearites and benmoreites, thereby lumping together both the $\mathrm{NaO}_{2}$ rich and the $\mathrm{K}_{2} \mathrm{O}$-rich varieties.

In our view, the nomenclature proposed by the IUGS Subcomission on the Systematics of Igneous Rocks (cf. Le Maitre, 1989) should be used, with sufficient allowance for the distinction of $\mathrm{Na}$ - or $\mathrm{K}$-enriched series.

Alkali basalts. These are porphyritic rocks with phenocrysts of irregularlyshaped olivine and idiomorphic yellowish augite-titanaugite set in a fine-grained intergranular matrix composed of zoned labradorite, clinopyroxene and opaques. A sample studied in this work contains $9 \%$ olivine, and corresponds to an olivine-rich alkali basalt. The rocks described by Almeida (1955) are olivine-free and have labradorite (zoned to andesine) and some spots of analcime in the matrix. Cornen (1986) denominated these rocks as hawaiites, but they are actually trachybasalts according to the IUGS nomenclature. Both our sample and that described by Almeida come from the same locality (a plug?) and present uneven concentrations of olivine, possibly as a result of internal fractionation by crystal settling. For that reason, only the name alkali basalt will be here used for 
these rocks.

Basaltic trachyandesites to trachyandesites. These rocks are mesocratic to leucocratic with alkali feldspar and feldspathoids and decreasing amounts of plagioclase. The mafic phenocrysts are clinopyroxene and amphibole. The pyroxene varies from yellowish augite-titanaugite in basaltic trachyandesites to greenish (sodic?) grains with augitic cores in trachyandesites. The amphibole is partially altered brown kaersutite, usually substituted by green clinopyroxene (soda augite?) and opaque grains along the borders. The felsic phenocrysts are fresh sanidine, isotropic altered feldspathoid (sodalite?) either as isolated idiomorphic crystals or as corroded aggregates and, rarely, some andesine laths and/or glomerules of alkali feldspar and oligoclase-andesine. The amount of phenocrysts varies from \pm 3 to $20 \%$ in different samples.

The matrix has a flow-oriented trachytic texture, particularly in the basaltic trachyandesites; in these rocks the cores of alkali feldspar laths are substituted by cryptocrystalline material and carbonate, possibly representing former plagioclase, while more typical trachyandesites have fresh homogeneous alkali feldspars. Other components of the matrix are idiomorphic isotropic feldspathoids of the sodalite family, titanite, green clinopyroxene, scarce amphibole, apatite and devitrified glass. Some samples present also rare flakes of strongly pleochroic brown biotite.

Trachytes. Alkali feldspar is the most abundant phenocryst and matrix mineral and occurs as independent laths or in aggregates together with plagioclase. Other phenocrysts are plagioclase, aegirineaugite, amphibole, altered feldspathoid, titanite and opaques. The plagioclase, which forms the larger phenocrysts (up to $\pm 1 \mathrm{~cm}$ ) and also microphenocrysts in some samples, is commonly zoned from andesine to oligoclase and bordered by alkali feldspar. The amphibole, originally idiomorphic, is almost totally converted to an aggregate of aegirine-augite and opaque grains. The idiomorphic feldspathoid is also totally altered to feathery natrolite plus cancrinite and calcite in most samples. The matrix is trachytic with predominance of flow-oriented alkali feldspars plus idiomorphic, altered feldspathoid, rods of aegirine-augite, opaques and rare apatite.

4 - Ultrabasic to basic dikes (tephrites, basanites and lamprophyres). These dikes intrude the pyroclastic rocks and cut the trachytic and phonolitic dikes, domes and plugs of the Remédios Formation (Fig. 1) and also each other (see Almeida, 1955, p. 28), except for the ankaratritic dikes (see below), which appear to be the youngest intrusions.

The rocks, black to gray in colour, are porphyritic with variable quantities (usually more than 15\%) of mafic phenocrysts and microphenocrysts (olivine and/or clinopyroxene, and sometimes amphibole). In some cases they also have minor amounts of a feldspathoid of the sodalite family (hauyne, nosean). The matrix is also mostly composed of mafic minerals and opaque grains. The felsic components are variable amounts of plagioclase, "anorthoclase", alkali feldspar and feldspathoid, although partially or totally glassy mesostasis is a common feature. Most dikes show abundant vugs filled with calcite and/or zeolites and chlorites.

These dikes are here separated in four groups, according to total amount of mafic minerals, characteristic mafic phenocryst assemblage, texture and composition of the felsic minerals in the matrix.

Group I, limburgitic dikes. In these rocks, the predominant phenocrysts are idio- to subidiomorphic titanaugitic clinopyroxene, appearing either as isolated crystals or in glomerules together with 
magnetite, accompanied by rounded, fresh, smaller olivine grains. In some samples, the phenocryst assemblage is set in a fresh glassy base with microlites of mafic minerals and needles of apatite. In others, the glass is partially altered or devitrified and the matrix clinopyroxene and opaque grains (sometimes associated with biotite) show larger size and idiomorphic outlines.

The name limburgite, very common in the literature on oceanic island rocks, is mainly a textural denomination for highly mafic alkalic rocks composed of olivine, clinopyroxene and magnetite phenocrysts with a glassy groundmass containing microlites of the same minerals and no feldspars (Le Maitre, 1989). As the composition of the felsic matrix cannot be ascertained under the microscope, the general use of this denomination as a Fernando de Noronha "rock type" may be misleading. Nevertheless, the name is here used for highly mafic rocks with a glassy base (see also Almeida, 1955), but the term will be extended to cover rocks with devitrified glass and the above mentioned phenocryst assemblage, without amphibole.

Group II, tephritic and basanitic dikes. These denominations are employed here to include all dikes with clinopyroxene as the dominant phenocryst phase and in which more or less altered olivine constitutes less than $10 \%$ of the rocks (occasionally, slightly more than $10 \%$ ), accompanied sometimes by magnetite grains. Also included are olivine- free tephritic dikes. The matrix is composed mainly of clinopyroxene and magnetite with variable contents (up to $20-35 \%$ ) of felsic groundmass. They may have some amphibole in the matrix (up to $2 \%$ ) as evenly distributed, slender or skeletal prisms. Some rocks are rich in apatite needles.

The clinopyroxene phenocrysts vary from yellowish, almost non-plechroic and slightly zoned salitic pyroxene, sometimes with greenish areas or patches, to pinkviolet strongly zoned titanaugites; the mineral may occur as isolated idiomorphic grains or appear in clusters, together with magnetite. Some of these clinopyroxenes are actually xenocrysts in these rocks (Ulbrich et al., 1994b). The groundmass is almost always partly glassy (with fresh or altered, devitrified or zeolitized glass) and partly crystalline, consisting of labradorite laths and some analcime or showing only slender poikilitic laths of alkali feldspar (in part, twinned "anorthoclase"), with or without analcime.

This is a heterogeneous group of rocks which, however, do not deserve special names, except perhaps for the analcime-rich varieties (analcime tephrites). Some of the pyroxene fourchites mentioned by Almeida (1955) will fall into this group (olivine-free rocks, with only small amounts of matrix amphiboles). Also, the holocrystalline olivine teschenites (Almeida, 1955) with 8-11\% olivine plus labradorite, some alkali feldspar and analcime in the matrix, can be defined as the coarser-grained equivalents of basanites or analcime basanites.

More groundmass-rich rocks, with less calcic plagioclase and/or alkali feldspar, will grade into phonolitic tephrites and tephritic phonolites.

Group III, amphibole-rich tephrite to melanocratic or tephritic lamprophyre dikes. This group includes amphibolebearing rocks having the main mineralogical and textural features similar to those of the tephrites described in Group II. The amphibole is a brown to reddish variety (possibly iron and titanium rich) appearing as slender prisms in the matrix and sometimes also as phenocrysts. There are no clear petrographic limits between the rocks of Group II and III.

In some tephrites, the amphibole is unevenly distributed in the matrix of the 
rocks. It is concentrated in irregular areas accompanying the other minerals and may also fill vugs together with some magnetite, zeolites and chloritic materials. In other rocks, the matrix is richer in slender amphibole prisms and the mineral appears more evenly distributed.

The phenocrystic amphibole is seen as rounded grains, partially or even totally substituted by minute opaque grains, sometimes accompanied by another generation of fresh brown amphibole crystals of variable size (up to $1 \mathrm{~cm}$ ). The development of amphibole in individual dikes is, on the whole, highly variable, resulting in three textural variations:

a) rocks with unevenly distributed amphibole in the matrix, with scarce altered amphibole phenocrysts, and with or without fresh amphibole phenocrysts.

b) almost aphyric rocks, with abundant amphibole in the matrix and no amphibole phenocrysts.

c) rocks with scarce amphibole in the matrix and abundant altered amphibole phenocrysts, with or without fresh phenocrystic amphibole.

The increase in amphibole content is accompanied, in all rocks, by other mineralogical changes. Olivine crystals, when present in rocks with amphibole, are altered to serpentine minerals with some carbonate; the alteration is complete in the rocks with larger amounts of amphibole. Sodalite group minerals (2-4\%) appear in rocks with abundant amphibole, particularly in those with plenty of amphibole phenocrysts; in some rocks, the feldspathoid (probably nosean) is colourless with a purplish hue and filled with tiny black inclusions, while in others it is bluish clean hauyne. The feldspathoids appear as idiomorphic to slightly rounded, partially resorbed microphenocrysts, occasionally present within pyroxene glomerules, and are also present in the matrix of some rocks. Abundant needles and tiny idiomorphic grains of apatite were observed in rocks with clear glassy groundmass. The amphibole-rich rocks of this group commonly contain xenoliths of ultramafic phaneritic rocks (e.g., clinopyroxene plus reddish, strongly pleochroic biotite). Xenocrysts of alkali feldspar and, more rarely, nepheline were also found in some of these lamprophyres (Ulbrich et al., 1994b).

The rocks of this group are classified as amphibole-rich tephrites when the amphibole is mainly confined to the matrix of the rocks. The denomination of melamocratic or lephritic lamprophyres is used for rocks with abundant amphibole phenocrysts; these rocks correspond mostly to the melamonchiquites of Almeida (1955) but also to some of his fourchites and maybe some of his nosean samnaites (Almeida, 1955).

Group IV, typical lamprophyres. The rocks have panidiomorphic, porphyriticglomeroporphyritic textures with phenocrysts of strongly pleochroic brown-red kaersutite, pink-violet titanaugite sometimes showing greenish (salitic?) irregular areas, magnetite and, eventually, very scarce serpentine pseudomorphs of olivine, in a matrix composed of prisms of clinopyroxene and amphibole, grains of magnetite and apatite needles, with $50 \%$ or more of felsic groundmass. In most rocks, andesineoligoclase is the main felsic mineral with variable amounts of interstitial analcime and fibrous zeolites. Some samples present a devitrified matrix composed of a feathery unidentified felsic mineral. The rocks are usually fresh, and contain abundant vugs and globular structures filled mainly with carbonate and also with zeolites and chloritic material. The camptonites described by Almeida belong to this group.

b) Dikes attributed to the Quixaba Formation Ankaratritic dikes. These rocks are 
very rich in mafic minerals, with olivine as the dominant phenocryst phase (15-25\%) accompanied by $5-8 \%$ clinopyroxene phenocrysts and having less than $10 \%$ of felsic groudmass, with nepheline as the common felsic mineral.

Olivine appears as irregularly shaped individuals, sometimes showing remnants of idiomorphic outlines; clusters of evenly sized grains are common in some samples. The grains (isolated or in clusters) are fresh and altered only along the borders and fractures to carbonate, some serpentine and talc; a yellow-brown spinel inclusion was identified in one olivine crystal. The clinopyroxene is a slightly zoned, yellow to pink-violet titanaugite and occurs as idioto subidiomorphic grains. Both mafic minerals show a seriate texture.

The matrix is essentially composed of clinopyroxene prisms and idiomorphic magnetite with scarce biotite flakes and interstitial poikilitc nepheline or analcime and devitrified glass. The rocks contain sparse xenocrysts of orthopyroxene bordered by aggregates of small titanaugite grains.

The name "ankaratrite" is here proposed for these dike rocks since their mineralogy and texture are practically identical to those shown by the ankaratrites lavas of the Quixaba Formation. Almeida (1955) recognized the similarity of these dikes with the Quixaba ankaratrites but used the name "tannbuschites" to register the absence of biotite in the analyzed dike samples and assigned them to the Remédios Formation. Biotite is, in any case, a minor accessory phase in both these dikes and the Quixaba ankaratrite flows, thus making it unnecessary to use a new rock name. These dikes do not cut Quixaba flows, but they are considered an intrusive part of the Quixaba ankaratrites, on account of petrographic similarities.

Olivine nephelinite. Only one dike of nephelinitic composition ( $>35 \%$ nepheline) was found intruding the tuffs of the Remédios Formation (see also Almeida, 1955). The rock is porphyritic with a phaneritic intergranular matrix, showing clusters of strongly pleochroic titanaugite crystals of more than $1 \mathrm{~cm}$. The clinopyroxene forms also smaller prisms (totalling 10-15\%) together with rounded partially altered olivine $(6-8 \%)$, abundant equant nepheline $(>35 \%)$ and opaque grains $( \pm 10 \%)$. The nepheline, with some analcime and zeolite as alteration products, presents inclusions of all the above mentioned minerals. Interstitial areas with analcime (and glass?) contain idiomorphic apatite and opaque grains, sometimes with associated biotite, alkali feldspar and rare anorthoclase. It is here tentatively assigned to the Quixaba Formation.

c) Flows and associated dikes of the Quixaba Formation and basanites of the Baía do Sancho.

Ankaratrite flows. The massive ankaratrite flow rocks are predominant and are black-greyish types with small (up to 2 $\mathrm{mm}$ ) mafic minerals in an aphanitic matrix, they present variable amounts of amygdules filled with carbonate or zeolites. Ankaratrites may appear also as reddish scoriaceous and highly amygdaloidal rocks (with calcite amygdules), breccias, tuffs, and cogenetic subvertical dikes intruding the ankaratritic flows.

The more common rocks, which appear as flows (more rarely as dikes), show abundant phenocrysts (10-20\%) of either idiomorphic to irregularly shaped or resorbed olivine, in a matrix with 40 to $50 \%$ of yellowish salitic clinopyroxene prisms, $15-20 \%$ of opaque grains and 15 to $25 \%$ of nepheline. Small amounts of reddish, strongly pleochroic biotite $(<1$ to $3 \%)$ and apatite needles appear in all rocks, while perovskite is an occasional accessory mineral, occurring mainly in rocks richer in olivine. Melilite appears in the matrix of some rocks (melilite ankarairites). 
The olivine can be totally fresh or partially altered. The alteration minerals, located along the borders and fractures of the crystals, are either fibrous serpentine and chlorite or reddish iron oxides. The pyroxene of the matrix is fresh and forms a tight net of prisms together with subidiomorphic opaque grains. Nepheline, which may be partly substituted by analcime in some rocks, appears as poikilitic small interstitial grains, the same habit commonly shown by biotites.

This rock type will be here called type $A$ ankaratrite, to distinguish it from the lighter coloured ankaratrites found in the Alto da Bandeira and close to the Ponta do Capim Açú (Fig.1). This second group, identified as type $B$ ankaratrite, is composed of rocks richer in clinopyroxene $( \pm$ $60-65 \%$ ) which appears as slightly zoned phenocrysts in the rocks. The amount of olivine in both types is not very different but the total amount of phenocrysts is higher in the type B ankaratrites.

In the literature, several names were applied to these rocks. The name ankaratrite was given by Almeida (1955) to characterize melanocratic olivine nephelinites containing some biotite (see also Le Maitre, 1989). Gunn \& Watkins (1976) and Schwab \& Bloch (1985) denominated them ankaramites (melanocratic basanites) because the rocks may have rare microlites of plagioclase in the matrix, Gunn \& Watkins (1976) also propose the name limburgites for these rocks on account of their color index, near 67 . Our study of 28 samples of ankaratrites from different localities performed during the present work did not reveal the presence of any feldspar, and the name limburgite is of course not approppriate for rocks with a crystalline matrix.

Weaver (1990) described the rocks as nepheline basalts, a terminology considered inapproppriate by the IUGS Subcomission on the Systematics of Igneous
Rocks (Le Maitre, 1989), since basalts are by definition rocks with plagioclase. The mentioned author also divides the ankaratrites on chemical grounds into two groups denominated nephelinites and basanites (which appear to correspond to our A- and B-type ankaratrites, respectively), on account of the quantities of normative nepheline. The name basanite, incidentally, is inappropriate for holocrystalline rocks without plagioclase.

In our view, the rocks have to be called melanocratic olivine nephelinites, although the varietal name "ankaratrite" is proper and should be maintained. Chemical and/or mineralogical special features should be added to a root name only as qualifiers, as proposed by the IUGS Subcomission (Le Maitre, 1989).

Nephelinite dike. Almeida (1955) recognized one dike of nephelinite intruding ankaratrites in the Pontinha (Fig. 1). It was also the only one found by us during sampling of the Quixaba flows. It is a phaneritic rock with pink-violet titanaugite bordered by green aegirine-augite, almost equant nepheline crystals, opaque grains, apatite and rare titanite, perovskite and biotite. The rock is porphyritic due to the larger size of some titanaugite prisms $(>1$ $\mathrm{cm})$. The pyroxene contains only apatite inclusions and some opaque grains in the greenish rims. Nepheline, on the other hand, shows inclusions of pyroxene, apatite and opaques. Interstitial areas are filled with chloritic alteration materials containing rounded to idiomorphic analcime grains.

Basanites of the Baia do Sancho. The basanitic rocks that form the subvertical pipe of the Baia do Sancho are porphyritic with $15-18 \%$ of subidiomorphic olivine grains partially or wholly converted into iddingsite and subordinate fresh yellowish titanaugite phenocrysts in a matrix constituted by clinopyroxene and about 20 - 
$25 \%$ of large poikilitic irregularly shaped plagioclase (labradorite-andesine), opaque grains $( \pm 6 \%)$, scarce apatite and biotite and relatively abundant interstitial analcime. Sampling along a vertical cross-section of the pipe shows that the amount of felsic minerals increases slightly in the upper levels, accompanied by some increase in the $\mathrm{Ab}$ content of the plagioclase (Ulbrich \& Ruberti, 1992).

d) Basanites of the Ilha de São José

The basanitic flows are composed of dark gray rocks with small mafic phenocrysts in an aphanitic matrix. Their most remarkable feature is that they bear abundant rounded mantle xenoliths of bottle-green dunites, blackish spinel peridotites (Iherzolites and harzburgites) and possibly also pyroxenites, with variable nodule dimensions (from 1-2 mm up to $30-40 \mathrm{~cm}$ ).

The basanites contain \pm 8 to $10 \%$ of mostly fresh olivine and equivalent amounts of yellowish, slightly pleochroic titanaugite as phenocrysts, in a matrix composed of clinopyroxene, opaque grains, plagioclase, apatite and interstitial poikilitic nepheline.

The texture of the matrix is very inhomogenous on a microscopic scale, commonly showing bands or lenses of different grain size and concentration of felsic minerals. The bands with larger grains contain about $15 \%$ of labradorite laths and $5-7 \%$ of nepheline representing the typical composition of basanites (Almeida, 1955) while the fine-grained areas appear to be almost free of felsic minerals: no plagioclase is here seen and only tiny spots of glass (or analcime?) are observed. These finer-grained areas resemble the matrix of some ankaratrites.

These basanites were grouped as the São José Formation by Almeida (1955) but probably represent the culmination of the Quixaba volcanism; they may be related, on petrographic grounds, to the Baia do Sancho basanite pipe.

\section{SUMMARY AND CONCLUSIONS}

1. The phenocryst assemblage of the Fernando de Noronha rocks is rather simple as is the case in most oceanic island (cf. Wilson, 1989). Predominant phenocrysts in the more basic types are $\mathrm{Ca}$-rich clinopyroxene, $\mathrm{Mg}$-rich olivine, magnetite and sometimes plagioclase; magmatic (but not xenocrystic) orthopyroxene is absent. Existing amphiboles (both as phenocrysts and/or in the matrix) are brownish to reddish kaersutites. Groundmass mineralogy is usually more varied. Strongly pleochroic biotite is very scarce, but frequent in the matrix of some rocks (e.g., flows and dike ankaratrites; also in essexite porphyries), or within coarse-grained enclaves found in lamprophyres and other rocks, where it coexists with varying proportions of other minerals (opaques, olivine, clinopyroxene, amphibole, feldspar, etc.); the mineral is never seen as phenocrysts. Olivine, on the other hand, although present as phenocrysts in more basic rocks, is absent in the groundmass; the exception is the alkali basalt where the mineral shows a seriate texture. Melilite was found only in the matrix of one ankaratrite sample. The term "anorthoclase", still a widely used mineral name, has been here applied to a finely twinned feldspar with low relief; the name should probably be dropped (Smith \& Brown, 1988) since it may represent a feldspar of ternary composition. Nepheline and members of the sodalite group (nosean, hauyne) are common as microphenocrysts and groundmass minerals.

2. The rocks of the Fernando de Noronha Archipelago were grouped into two formations by Almeida (1955). The oldest one is the Remédios Formation (ages about $12-8 \mathrm{Ma}$ ) with lapilli tuffs, breccias and agglomerates as basal unit, invaded by a large petrographic variety of intrusive domes, sills, plugs and dikes of alkali ba- 
salts, tephrites, phonolitic tephrites, tephritic phonolites, phonolites, trachytes, trachyandesites, basanites, several types of lamprophyres and some of the intrusive equivalents of phonolites, tephrites and intermediate rocks (foid monzogabbros and monzosyenites, essexite porphyries). The rocks of the Quixaba Formation (ages about 1-2 Ma) were deposited after an erosional hiatus. Predominant are ankaratrite flows and some associated dikes of ankaratrites and nephelinites. The basanite flows of the Ilha de São José were assigned to the younger São José Formation by Almeida (1955) but may represent the waning stages of the Quixaba volcanic event.

3. The Remédios Formation, petrographically and structurally rather complex, shows a basal pyroclastic sequence and a subsequent overlap and recurrence of intrusions of several rock types. At least two petrographic lineages are recognized, one made up by the potassic alkali basalt-trachyandesite-trachyte series and the other by the Na-enriched basanite-tephrite-phonolite series (together with their coarser-grained counterparts such as essexite porphyries; cf. also Almeida, 1955). Similar series are recognized in many oceanic islands (e.g. Wilson, 1989). Parental magmas for the two series may be represented by alkali basalts and basanites for the $\mathrm{K}$-rich and the Na-enhanced lineages, respectively. The Remédios limburgites (Group I dikes) and the typical lamprophyres (Group IV dikes) are of uncertain ancestry.

4. The Quixaba rocks are structurally and petrographically simpler than those of the older Formation, and are composed mainly by the A- and B-type ankaratrite flows and some basanite intrusions, natural members of a sodic series. The ankaratrite dikes ("tannbuschites"; Almeida, 1955) found as younger intrusions within the Remédios rocks are petrographically similar to the Quixaba ankaratrite flows and are here considered a part of the Quixaba volcanic event. The basanite flows of the Ilha de São José are correlated with the basanite pipe of Baia do Sancho, and tentatively included in the Quixaba Formation.

5. The geologic features indicate that the main island represents a poorly exposed "central volcanic complex" (Furnes \& Stillman, 1987), capped by younger volcanic rocks. The rocks of the Remédios Formation crystallized and/or differentiated in layered and/or compositionally inhomogeneous magma chambers. This explains, on the one hand, the appearance of phonolitic domes composed almost entirely either by porphyritic or aphyric rocks (Almeida, 1955), signalling that these intrusions were made up by magmas drawn from different levels and/or different parts of a deeper-seated magma chamber. On the other hand, the presence of coarse-grained rocks - such as the essexite porphyry sheet and the blocks and enclaves of plutonic rocks in the agglomerates and dikes clearly indicates that portions of these magmas crystallized slowly at depth.

6. Enclaves of coarse-grained rocks are found in many Remédios lamprophyre dikes, as well as xenocrysts of magmatic origin (e.g. fragments of alkali feldspars or nepheline coexisting with clinopyroxene and altered olivine in Group III dikes). Many of these enclaves present a mineralogy that is consistent with that of the host dikes (Ulbrich et al., 1994b), suggesting that many phenocrysts in these dikes may actually represent dispersed enclaves drawn from different levels of the partly crystallized deeper-seated magma chambers ("cogenetic crystal-magma mixing"). On the other hand, these features may be an indication that the different magmas corresponding to both $\mathrm{Na}$ - and $\mathrm{K}$-enhanced Remédios rock series actually coexisted, at least in part, and could mix with each other. 


\section{ACKNOWLEDGMENTS}

V.Maringolo and specially E.Ruberti are thanked for help during sample collection. Discussions with Dr. D.Velde during the field trip and with V.Maringolo on the petrography and possible genetic relationship of the dike rocks helped clear up some obscure aspects. V.Claro Sanches collaborated with laboratory work. H.Ulbrich is thanked for discussions on petrographic nomenclature and for advice on the text. The São Paulo FAPESP Agency provided financial support for the field trip to Fernando de Noronha.

\section{REFERENCES}

ALMEIDA, F.F.M. (1955) Geologia e petrologia do Arquipélago de Fernando de Noronha. Monografía. Divisão de Geologia e Mineralogia. DGM, 13:1181.

BRYAN, G.M:; KUMAR, N.; CASTRO, P. J. (1972) The north Brazilian Ridge and the extension of equatorial fracture zones into the continent. In: CONGRESSO BRASILEIRO DE GEOLOGIA, 26., Belém. 1972. Anais, Belém, SBG. v. 2, p.133-144.

CHAFFEY, D.J.; CLIFF, R.A.; WILSON, B.M. (1989) Characterization of the St Helena magma source. In: SAUNDERS, A.D.; NORRY, M.J. (eds.) Magmatism in the Ocean Basins. p.257-276. (Geological Society Special Publication, 42).

CORDANI, U.G. (1970) Idade do vulcanismo no Oceano Atlântico Sul. Boletim IGA, 1:9-75.

CORNEN, G. (1986) Identification des séries magmatiques de lile brésilienne de Fernando de Noronha (Atlantique Sud). Comptes Rendus Hebdomadaires des Seances de I'Académie des Sciences. Serie II, 303(16): 1455-1460.
COX, K.G.; BELL, J.D.; PANKURST, R.J. (1979) The Interpretation of Igneous Rocks. London, Allen \& Unwin, $450 \mathrm{p}$.

DAVIES, G.R.; NORRY, M.J.; GERLACH, D.C.; CLIFF, R.A. (1989) A combined chemical and $\mathrm{Pb}-\mathrm{Sr}$ isotopic study of the Azores and Cape Verde hot-spots: the geodynamic implications. In: SAUNDERS, A.D.; NORRY, M.J. (eds.) Magmatism in the Ocean Basins. p.231-255. (Geological Society Special Publication, 42).

FURNES, H.; STILLMAN, C.J. (1987) The geochemistry and petrology of an alkaline lamprophyre sheet intrusion complex on Maio, Cape Verde Republic. Journal of the Geological Society. London, 144:227-241.

GERLACH, D.C.; STORMER, J.C.; MUELLER, P.A. (1987) Isotopic geochemistry of Fernando de Noronha. Earth and Planetary Science Letters, 85:129-144.

GUNN, B.M; WATKINS, N.D. (1976) Geochemistry of the Cape Verde Islands and Fernando de Noronha. Geological Society of America Bulletin, 87:1089. 1100 .

LE MAITRE, R.W. (Ed.) (1989) Classification of igneous rocks and glossary of terms: recomendations of the International Union of Geological Sciences Subcomission on the Systematics of Igneous Rocks. Oxford, Blackwell $193 \mathrm{p}$.

MITCHELL-THOME, R (1970) Geology of the South Atiantic Islands. Berlin, Gebrüder Borntraeger. 367p. (Beiträge zur Regionalen Geologie der Erde, 10).

SCHMINCKE, H.U. (1982) Volcanic and chemical evolution of the Canary Islands. In: RAD, V. von; HINZ, K. SARTHEIN, M.; SEIBOLD, E. (eds) Geology of the Northwest African Continental Margin. Berlin, Springer- 
Verlag. p.273-306.

SCHWAB, R.G.; BLOCH, W. (1985) Geochemical distribution patterns of magmatites from the Archipelago of Fernando de Noronha. Zentralblatt fír Geologie und Paläntologie. Teil 1: $1477-1483$

SMITH, J.V;; BROWN, W.L. (1988) Feldspar Minerals. 2.ed., Germany, Springer-Verlag. 828 p. v. 1 .

SUN, S.-S.; McDONOUGH, W.F. (1989) Chemical and isotopical systematics of oceanic basalts: implications for mantle composition and processes. In: SAUNDERS, A.D; NORRY, M.J. (eds.) Magmatism in the Ocean Basins. p.313-345. (Geological Society Special Publication, 42).

ULBRICH, M.N.C.; RUBERTI, E. (1992)

Nova ocorrência de rochas basaniticas no Arquipélago de Fernando de Noronha. In: CONGRESSO BRASILEIRO DE GEOLOGIA, 37., São Pau1o, 1992. Boletim Resumos Expandidos, São Paulo, SBG. v.2, p.83-84.

ULBRICH, M.N.C; MARINGOLO, V.; RUBERTI, E. (1994a) Geochemistry of alkaline volcanic-subvolcanic rocks from the Brasilian Fernando de Noronha Ar- chipelago, Southern Atlantic Ocean Geochimica Brasiliensis, 8(1):21-39. ULBRICH, M.N.C; MARINGOLO, V: VLACH, S.R.F. (1994b) Xenocrysts in mafic dikes from the Fernando de Noronha Archipelago. In: INTERNATIONAL SYMPOSIUM ON THE PHYSICS AND CHEMISTRY OF THE UPPER MANTLE, São Paulo, 1994. Extended Abstracts. São Paulo, CPRM/FAPESP. p.36-38.

WEAVER, B.L. (1990) Geochemistry of highly-undersaturated ocean island basalt suites from the South Atlantic Ocean: Fernando de Noronha and Trindade Islands. Contributions to Mineralogy and Petrology, 105:502-515.

WEAVER, B.L. (1991) The origin of ocean island basalt end-member compositions: trace element and isotopic constraints. Earth and Planetary Science Letters, 104:381-397.

WILKINSON, J.F.G. (1974) The mineralogy and petrography of alkali basaltic rocks. In: SØRENSEN, H. (ed.) The Alkaline Rocks. London, John Wiley \& Sons. p.67-95.

WILSON, M. (1989) Igneous Petrogenesis. London, Unwin Hyman. 466p.

M.N.C.Ulbrich - Departamento de Mineralogia e Petrologia, Instituto de Geociências/USP - Caixa Postal 11.348 CEP 05422-970 Såo Paulo, Brasil. 